\title{
Evidence for submarine weathering from metamorphosed weathering profiles on basaltic rocks, Tananao Metamorphic Complex, Taiwan ${ }^{1}$
}

\author{
Tzen-Fu Yui ${ }^{\mathrm{a}}$, Tsai-Way Wu ${ }^{\mathrm{b}}$, Yunshuen Wang ${ }^{\mathrm{c}}$, Ching-Hua Lo ${ }^{\mathrm{d}}$, Chia-Yu Lu ${ }^{\mathrm{d}}$ \\ anstitute of Earth Sciences, Academia Sinica, Taipei, Taiwan, ROC \\ ${ }^{b}$ Department of Geology, University of Western Ontario, London, Ont. N6A 5B7, Canada \\ ${ }^{\circ}$ Central Geological Survey, MOEA, Taipei, Taiwan, ROC \\ ${ }^{d}$ Department of Geology, National Taiwan University, Taipei, Taiwan, ROC
}

Received 23 July 1993; revision accepted 5 May 1994

\begin{abstract}
The metamorphosed paleo-weathering horizon(s) developed on basaltic rocks in the Tananao Metamorphic Complex forms distinct $\mathrm{Al}-\mathrm{Fe}$-rich rocks and occurs as two parallel belts, demonstrating its potential as a stratigraphic correlation unit in this structurally complicated metamorphic terrain.

These Al-Fe-rich rocks have been metamorphosed under amphibolite-/greenschist-facies conditions, leading to the formation of garnet-chloritoid rocks/chloritoid-rich rocks. The chemical changes along three profiles, from metabasite to garnet-chloritoid rock, show prominent $\mathrm{K}, \mathrm{Rb}, \mathrm{Cs}$ and $\mathrm{Ba}$ enrichment, yet, also, a large depletion of other elements if it is assumed that $\mathrm{Ti}, \mathrm{Zr}, \mathrm{Nb}, \mathrm{Ta}$ and $\mathrm{Hf}$ remained relatively immobile. The REE's, however, behaved non-coherently. These chemical characteristics are attributed to pre-metamorphic processes and are shown to be similar to those observed with submarine weathering of basaltic rocks. In contrast, the chloritoid-rich rocks reveal distinct $\mathrm{K}, \mathrm{Rb}, \mathrm{Cs}$ and $\mathrm{Ba}$ depletion. It is suggested that this resulted from subaerial weathering processes.

$\mathrm{K}$ enrichment is not an uncommon feature in Paleozoic/Precambrian paleosols. The present case study demonstrates that submarine weathering should be considered as a probable cause.
\end{abstract}

\section{Introduction}

The study of paleosols of Quaternary age has made a significant contribution to stratigraphic and paleoenvironmental research (e.g., Birkeland et al., 1971; Campbell, 1986). Similar applications when extended to pre-Quaternary paleosols, however, are restricted due to the possibility of complicated geohistory (see

[SB]

${ }^{1}$ Institute of Earth Sciences Contribution No. IESEP94-014.
Wright, 1986). For example, since soils often change their characteristicss along strike and more than one soil may be present in a stratigraphic sequence, their use as correlation units in a metamorphic terrain may be somewhat ambiguous (Barrientos and Selverstone, 1987). On the other hand, using Paleozoic and Precambrian paleosols as indicators of ancient atmospheric conditions (Gay and Grandstaff, 1980; Schau and Henderson, 1983; Holland, 1984; Retallack, 1986) is meaningful only when the alteration processes can be correctly identified ( Hol- 
land and Feakes, 1989; Palmer et al., 1989a, b; Retallack, 1989; Rainbird et al., 1990). This paper presents chemical changes of the metamorphosed paleo-weathering profiles developed on basaltic rocks, probably of late Permian age in the Tananao Metamorphic Complex of Taiwan. The anomalous $\mathrm{K}$ enrichment along the profiles is as most likely a result of submarine weathering. It is postulated that such a process should be considered a probable cause for those Paleozoic and Precambrian paleosols with similar chemical variation trends. In addition, the spatial distribution of such metamorphosed weathering horizon (s) in the Tananao Metamorphic Complex suggests its potential as a stratigraphic indicator.

\section{Geological settings and occurrences}

The Tananao Metamorphic Complex is the oldest geologic-tectonic element outcropping in Taiwan. Schists, metabasite, marble and granitic gneiss are the major rock types, with the presence of subordinate amounts of metasandstone, metaconglomerate, metachert and ophiolitic rocks. Four mappable lithologic units were proposed (Wang Lee, 1982; Hsu, 1988). Unit I consists of a metabasite-metachert-marble association. A few deformed fossils of late Permian age were recovered from the marbles in this unit (Yen, 1953). It was shown that most metabasites in this unit exhibit chemical characteristics similar to those of within-plate basalt, and it was postulated that this unit may represent ancient ocean (marginal/back arc basin) floors/islands associated with chert and calcareous sediments (Yui et al., 1990a). Unit II is composed of pure and massive marble and was interpreted as reefy limestones (Yui et al., 1988, 1990b). Unit III contains phyllite, graphite schist, metasandstone and metaconglomerate, associated with minor blocks of metasandstone, metaconglomerate, metachert, marble and metabasite. Its mélange nature (Lu, 1986) suggests that it could represent a trench or near-trench deposit. Dinoflagellate fossils were reported recently (C.H. Chen, 1989 ), indicating that part of this unit may have ranged in age from the middle Jurassic to the early Cretaceous. The last unit, Unit IV, consists of granitic gneisses intruding into the above lithologic units at $~ 97-85 \mathrm{Ma}$ (Jahn et al., 1986; Yui et al., 1993). The contact between rock types is generally concordant. The foliation of all these rocks generally strikes in the NE-SW direction and dips predominantly to the NW. However, due to the intensive deformation and polymetamorphism as well as the lack of diagnostic fossils, stratigraphic relationships among these rocks are still unclear. Tentative tectonic models for this metamorphic complex were discussed by Liou and Ernst (1984) and Yui et al. (1988, 1990b).

The chloritoid-rich rocks, occurring as a series of lenticular pods and lenses in the chloritoidbearing greenschist intercalated with the marble in Unit I, were first reported by Yen (1959). P.Y. Chen (1963) reported that the size of these lenticular bodies may range from $<1$ up to $\sim 8 \mathrm{~m}$ in thickness and a few tens of meters in length. These lenticular bodies can be traced for $\sim 1 \mathrm{~km}$ along the rock foliation. Based on drilling data, at least two successive layers of such rocks were noted in some places. Later, Liou and Chen (1978) gave petro-/mineral-chemical data and concluded that these chloritoid-rich rocks are $\mathrm{Al}-$ Fe-rich and were most probably derived from paleo-lateritic soils formed from a basaltic layer in a limestone terrain. The mineral assemblage, chloritoid + chlorite + calcite + opaques (mainly magnetite and ilmenite) \pm quartz \pm corundum \pm white mica \pm epidote \pm sphene \pm rutile, demonstrates that these paleosols were later metamorphosed under greenschist-facies metamorphic conditions (i.e. $350-450^{\circ} \mathrm{C}, \sim 2 \mathrm{kbar}$ ) (Liou and Chen, 1978).

In their paper, Liou and Chen (1978) showed four sample localities for the chloritoid-rich rocks (Fig. 1, sample localities $1-4$ ). In recent years with further field work, the authors of this study have found the chloritoid-rich rocks in another four localities (Fig. 1, sample localities 5-8). These newly-found occurrences are all intercalated with marble, similar to those reported by P.Y. Chen (1963) and Liou and Chen (1978). It is most surprising that all these chloritoid-rich 


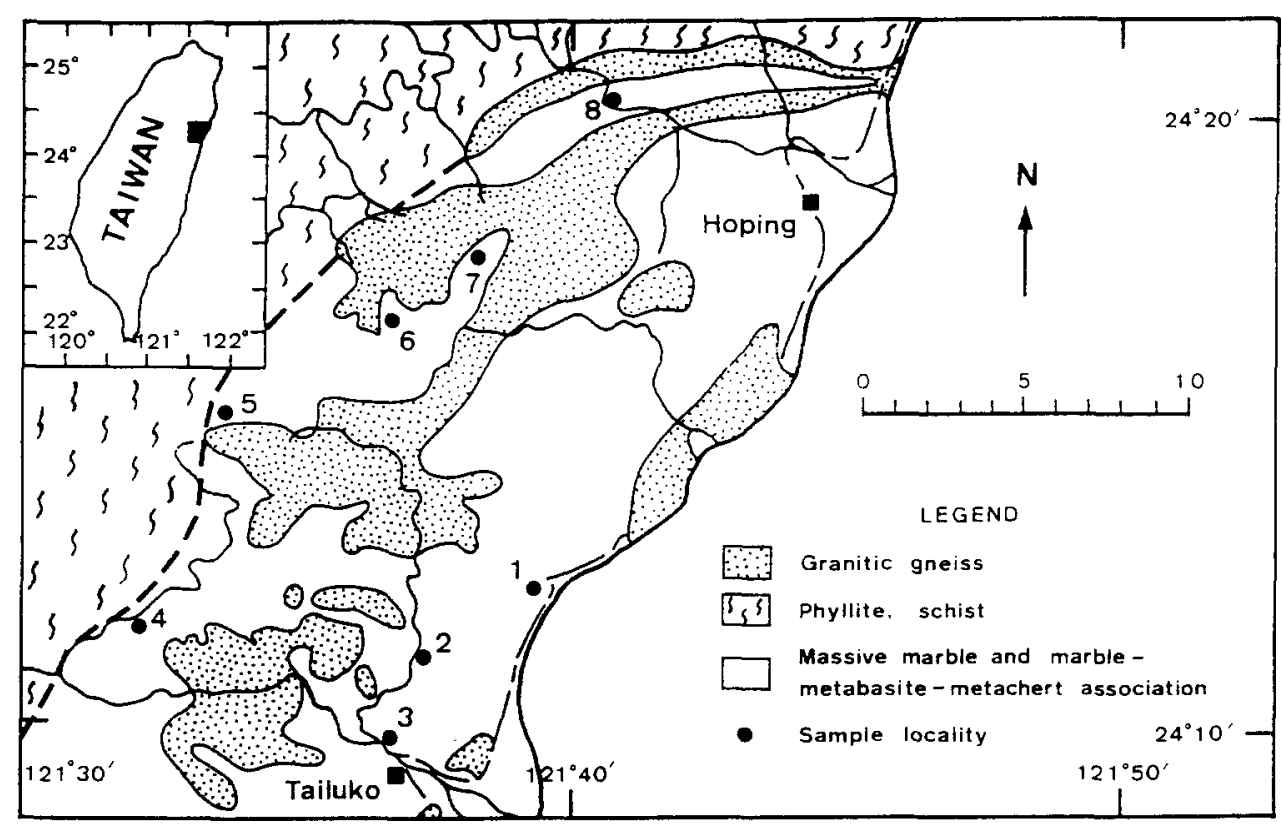

Fig. 1. Simplified geologic map of the study area (modified after Lan, 1989), showing the distribution of the lithologic units mentioned in the text and the sample localities. Sequential samples from the LI, P and LII profiles are from locality 8 ; sample 7999 , from locality 7 ; sample 7925 , from locality 6 ; sample 7966 , from locality 5 ; sample 0070 , from locality 4 ; sample 8430 , from locality 3 ; sample 7523 , from locality 2 ; and samples 1120 and 1121 , from locality 1 .

rock occurrences spatially form two belts, roughly parallel to the main trend of the rock foliation (Fig. 1). Although, due to the complicated structures of the area, the present study does not speculate on how these two belts are related to each other; such a spatial distribution, as well as the similar rock association, at least give a reasonable argument for trying to use these rocks as a stratigraphic indicator in the Tananao Metamorphic Complex. Similar recommendations concerning the paleosols in the Eastern Alps of Central Europe were also proposed by Barrientos and Selverstone (1987) and Krois et al. (1990).

Among the newly-found occurrences, the chloritoid-rich rocks at locality 8 show two distinct aspects. First, they reveal a different mineral assemblage from others. At this locality, the mineral composition includes garnet, chloritoid, white mica, chlorite, plagioclase, quartz, epidote and ilmenite (hereafter referred to as the garnetchloritoid rock), indicating amphibolite-facies metamorphic conditions. Secondly, this garnet- chloritoid rock is associated with metabasite and the gradational changes from one to the other can be observed. The metabasite at this locality is $\sim 8$ $m$ thick and can be divided into three units: the lower lava flow (LI) $(\sim 3.5 \mathrm{~m})$, the middle pillow (P) $(\sim 1 \mathrm{~m})$ and the upper lava flow (LII) $(\sim 3.5 \mathrm{~m})$. The lower $3 \mathrm{~m}$ of each lava flow and the pillow core are typical metamorphosed amphibolite-facies basaltic rocks, containing hornblende, plagioclase, biotite, white mica and opaques. The garnet-chloritoid rocks developed on the upper $30-50 \mathrm{~cm} /$ outer $10-20 \mathrm{~cm}$ of the lava flows and the pillows, respectively, with the amount of garnet, chloritoid and white mica increasing upward/outward progressively. The grain size of the garnet reaches $3-5 \mathrm{~mm}$ and is easily recognized in the field. Sequential samples, from metabasite (sample numbers with suffix A) to garnet-chloritoid rock (sample numbers with suffix B, C, or D), were collected from three profiles of LI, P and LII to see their chemical changes. Sampling was focused on the garnet-chloritoid rocks, while sampling dis- 
tances were arbitrary. For comparison, eight samples of chloritoid-rich rocks from other localities were also studied.

\section{Analytical methods and results}

All chemical analyses were performed at the

Table 1

Chemical compositions of three profiles from metabasite to garnet-chloritoid rock at locality 8

\begin{tabular}{|c|c|c|c|c|c|c|c|c|c|c|c|}
\hline & LI-A & LI-B & LI-C & LI-D & PI-A & PI-B & PI-C & LII-A & LII-B & LII-C & LII-D \\
\hline \multicolumn{12}{|l|}{$(\%):$} \\
\hline $\mathrm{SiO}_{2}$ & 45.48 & 39.16 & 35.40 & 28.01 & 47.54 & 39.17 & 31.99 & 45.83 & 34.82 & 33.29 & 23.83 \\
\hline $\mathrm{TiO}_{2}$ & 1.66 & 2.86 & 4.41 & 6.76 & 1.66 & 2.05 & 3.76 & 1.65 & 3.76 & 4.60 & 5.42 \\
\hline $\mathrm{Al}_{2} \mathrm{O}_{3}$ & 15.59 & 19.96 & 23.47 & 26.01 & 14.13 & 17.19 & 25.68 & 13.81 & 24.05 & 25.67 & 29.95 \\
\hline $\mathrm{FeO}^{\mathrm{a}}$ & 11.88 & 16.15 & 20.18 & 23.13 & 11.06 & 17.97 & 18.85 & 12.22 & 20.13 & 19.23 & 19.91 \\
\hline $\mathrm{MnO}$ & 0.18 & 0.21 & 0.28 & 0.09 & 0.18 & 0.22 & 0.15 & 0.22 & 0.25 & 0.21 & 0.15 \\
\hline $\mathrm{MgO}$ & 9.79 & 9.61 & 4.61 & 2.65 & 10.49 & 8.06 & 4.85 & 12.73 & 6,18 & 3.99 & 4.94 \\
\hline $\mathrm{CaO}$ & 11.26 & 5.39 & 1.68 & 1.32 & 11.01 & 8.78 & 2.58 & 8.16 & 1,12 & 2.95 & 3.40 \\
\hline $\mathrm{K}_{2} \mathrm{O}$ & 0.12 & 0.89 & 2.73 & 2.17 & 0.03 & 0.15 & 1.97 & 0.01 & 2.29 & 2.12 & 1.03 \\
\hline $\mathrm{Na}_{2} \mathrm{O}$ & 1.58 & 0.92 & 0.63 & 0.37 & 1.44 & 0.60 & 1.10 & 0.16 & 0.46 & 0.98 & 0.35 \\
\hline $\mathrm{P}_{2} \mathrm{O}_{5}$ & 0.26 & 0.38 & 0.71 & 0.88 & 0.25 & 0.35 & 0.16 & 0.27 & 0.09 & 0.35 & 0.61 \\
\hline LOI & 2.20 & 4.16 & 5.40 & 7.53 & 2.23 & 4.57 & 8.08 & 4.45 & 6.10 & 5.92 & 9.68 \\
\hline Total & $\overline{100.00}$ & $\overline{99.69}$ & $\overline{99.50}$ & $\overline{98.92}$ & $\overline{100.02}$ & $\overline{99.11}$ & $\overline{99.17}$ & $\overline{99.51}$ & $\overline{99.27}$ & $\overline{99.31}$ & $\overline{99.27}$ \\
\hline \multicolumn{12}{|l|}{ (ppm): } \\
\hline $\mathrm{Nb}$ & 25 & 49 & 54 & 97 & 23 & 27 & 59 & 23 & 54 & 72 & 89 \\
\hline $\mathrm{Zr}$ & 117 & 190 & 322 & 434 & 118 & 141 & 320 & 119 & 278 & 409 & 471 \\
\hline$Y$ & 20 & 34 & 57 & 127 & 22 & 25 & 27 & 22 & 30 & 54 & 56 \\
\hline $\mathrm{Sr}$ & 600 & 232 & 243 & 251 & 233 & 170 & 382 & 194 & 166 & 252 & 285 \\
\hline $\mathrm{Rb}$ & 4 & 34 & 87 & 65 & 2 & 5 & 47 & 3 & 54 & 65 & 34 \\
\hline $\mathrm{Ba}$ & 54 & 383 & 580 & 681 & 37 & 52 & 1,560 & 28 & 1,560 & 808 & 279 \\
\hline $\mathrm{Zn}$ & 77 & 98 & 144 & 248 & 88 & 135 & 187 & 103 & 158 & 169 & 264 \\
\hline $\mathrm{Ni}$ & 284 & 318 & 459 & 1,005 & 279 & 355 & 315 & 270 & 382 & 371 & 212 \\
\hline Co & 61 & 65 & 96 & 149 & 59 & 72 & 86 & 63 & 87 & 89 & 75 \\
\hline $\mathrm{Cr}$ & 529 & 976 & 1,081 & 1,206 & 522 & 735 & 750 & 496 & 1,340 & 948 & 1,001 \\
\hline V & 277 & 331 & 629 & 889 & 253 & 343 & 453 & 265 & 427 & 590 & 545 \\
\hline $\mathrm{Ta}$ & 1.23 & 2.84 & 3.28 & 5.91 & 1.14 & 1.46 & 3.46 & 1.34 & 3.04 & 4.19 & 3.04 \\
\hline Hf & 2.68 & 4.31 & 7.84 & 9.36 & 2.5 & 3.27 & 7.34 & 2.75 & 6.32 & 8.17 & 5.75 \\
\hline $\mathrm{Sc}$ & 32.8 & 41.8 & 54.2 & 77.5 & 32.6 & 39.3 & 46.7 & 32.1 & 51.8 & 52.9 & 53.4 \\
\hline Cs & 0.21 & 0.98 & 2.35 & 1.15 & n.d. & n.d. & 0.89 & n.d. & n.d. & 2.52 & n.d. \\
\hline Th & 1.9 & 4.4 & 4.2 & 6.8 & 1.6 & 2.2 & 4.6 & 1.6 & 3.6 & 5.6 & 3.2 \\
\hline $\mathrm{La}$ & 15.8 & 37.2 & 43.6 & 109.0 & 16.5 & 19.1 & 23.1 & 16.6 & 39.8 & 131.0 & 74.9 \\
\hline $\mathrm{Ce}$ & 33.4 & 78.5 & 97.6 & 244.0 & 36.4 & 44.0 & 39.9 & 37.3 & 66.7 & 210.0 & 110.0 \\
\hline $\mathrm{Nd}$ & 16.7 & 36.4 & 54.3 & 131.0 & 19.6 & 22.7 & 25.7 & 20.3 & 37.7 & 57.5 & 65.4 \\
\hline $\mathrm{Sm}$ & 3.88 & 7.04 & 12.20 & 32.80 & 4.50 & 5.27 & 6.52 & 4.67 & 7.49 & 18.10 & 12.90 \\
\hline $\mathrm{Eu}$ & 1.48 & 2.52 & 4.20 & 6.92 & 1.39 & 1.85 & 1.09 & 1.34 & 2.05 & 4.35 & 2.15 \\
\hline Gd & 4.22 & 6.88 & 12.50 & 20.80 & 4.29 & 5.05 & 5.87 & 4.13 & 7.19 & 14.20 & 8.19 \\
\hline $\mathrm{Tb}$ & 0.72 & 1.09 & 2.03 & 2.82 & 0.66 & 0.79 & 0.83 & 0.62 & 1.04 & 1.87 & 1.10 \\
\hline $\mathrm{Yb}$ & 1.96 & 2.96 & 4.75 & 7.96 & 1.73 & 2.18 & 2.05 & 1.67 & 2.25 & 3.51 & 2.54 \\
\hline $\mathrm{Lu}$ & 0.30 & 0.47 & 0.68 & 0.96 & 0.23 & 0.28 & 0.27 & 0.23 & 0.37 & 0.49 & 0.42 \\
\hline$(\mathrm{La} / \mathrm{Yb})_{\mathrm{N}}$ & 5.3 & 8.3 & 6.0 & 9.0 & 6.3 & 5.8 & 7.4 & 6.6 & 11.7 & 24.6 & 19.5 \\
\hline $\mathrm{CIW}^{\mathrm{b}}$ & 40 & 64 & 85 & 90 & 39 & 50 & 80 & 48 & 90 & 79 & 82 \\
\hline
\end{tabular}

n.d. = not determined.

a Total $\mathrm{Fe}$ as $\mathrm{FeO}$.

${ }^{b} \mathrm{CIW}$ (weathering index) $=\left[\mathrm{Al}_{2} \mathrm{O}_{3} /\left(\mathrm{Al}_{2} \mathrm{O}_{3}+\mathrm{CaO}+\mathrm{Na}_{2} \mathrm{O}\right)\right] \times 100$ (molecular proportions) (Harnois, 1988). 
Table 2

Chemical compositions of chloritoid-rich rocks from localities $1-7$

\begin{tabular}{|c|c|c|c|c|c|c|c|c|}
\hline & 1120 & 7925 & 0070 & 8430 & 7523 & 7966 & 7999 & 1121 \\
\hline \multicolumn{9}{|l|}{$(\%)$} \\
\hline $\mathrm{SiO}_{2}$ & 31.92 & 29.01 & 27.11 & 26.59 & 22.49 & 17.66 & 16.15 & 12.57 \\
\hline $\mathrm{TiO}_{2}$ & 5.05 & 4.73 & 4.31 & 5.43 & 5.63 & 4.08 & 5.03 & 6.57 \\
\hline $\mathrm{Al}_{2} \mathrm{O}_{3}$ & 28.10 & 31.14 & 32.91 & 30.98 & 35.16 & 45.49 & 43.30 & 42.33 \\
\hline $\mathrm{FeO}^{\mathrm{a}}$ & 25.15 & 25.40 & 22.90 & 26.50 & 24.91 & 21.72 & 24.97 & 26.61 \\
\hline $\mathrm{MnO}$ & 0.37 & 0.19 & 0.20 & 0.19 & 0.21 & 0.19 & 0.10 & 0.16 \\
\hline $\mathrm{MgO}$ & 1.26 & 0.88 & 1.61 & 1.00 & 2.19 & 1.05 & 1.87 & 1.84 \\
\hline $\mathrm{CaO}$ & 0.71 & 0.90 & 1.13 & 0.89 & 0.36 & 3.19 & 1.13 & 0.20 \\
\hline $\mathrm{K}_{2} \mathrm{O}$ & 0.15 & 0.01 & 0.32 & 0.00 & 0.14 & 0.00 & 0.00 & 0.00 \\
\hline $\mathrm{Na}_{2} \mathrm{O}$ & 0.00 & 0.00 & 1.45 & 0.00 & 0.00 & 0.00 & 0.00 & 0.00 \\
\hline $\mathrm{P}_{2} \mathrm{O}_{5}$ & 0.36 & 0.67 & 0.32 & 0.69 & 0.19 & 0.79 & 0.56 & 0.19 \\
\hline LOI & 6.18 & 6.62 & 6.83 & 7.34 & 7.73 & 6.01 & 6.57 & 8.74 \\
\hline Total & $\overline{99.24}$ & $\overline{99.57}$ & $\overline{99.08}$ & $\overline{99.60}$ & 99.00 & $\overline{100.18}$ & $\overline{99.69}$ & $\overline{99.20}$ \\
\hline \multicolumn{9}{|l|}{$(\mathrm{ppm})$} \\
\hline $\mathrm{Nb}$ & 62 & 49 & 60 & 59 & 85 & 65 & 55 & 79 \\
\hline $\mathrm{Zr}$ & 341 & 295 & 281 & 319 & 440 & 441 & 361 & 383 \\
\hline Y & 29 & 18 & 42 & 21 & 21 & 18 & 10 & 10 \\
\hline $\mathrm{Sr}$ & 90 & 32 & 499 & 31 & 39 & 236 & 36 & 2 \\
\hline $\mathrm{Rb}$ & 6 & 3 & 7 & 3 & 4 & $<2$ & 2 & $<2$ \\
\hline $\mathrm{Ba}$ & 59 & 27 & 190 & 6 & 81 & 45 & 20 & 6 \\
\hline $\mathrm{Zn}$ & 238 & 160 & 174 & 170 & 216 & 130 & 166 & 175 \\
\hline $\mathrm{Ni}$ & 356 & 298 & 428 & 352 & 267 & 78 & 158 & 41 \\
\hline Co & 94 & 49 & 105 & 55 & 87 & 57 & 61 & 27 \\
\hline $\mathrm{Cr}$ & 298 & 788 & 1,017 & 872 & 654 & 1,103 & 1,622 & 1,324 \\
\hline V & 475 & 418 & 611 & 482 & 564 & 437 & 335 & 688 \\
\hline $\mathrm{Ta}$ & 2.88 & 2.82 & 3.32 & 3.15 & 6.90 & 3.34 & 3.14 & 4.36 \\
\hline $\mathrm{Hf}$ & 6.19 & 6.80 & 6.28 & 7.34 & 16.90 & 7.32 & 7.77 & 8.25 \\
\hline $\mathrm{Sc}$ & 36.8 & 39.1 & 58.3 & 45.2 & 53.4 & 42.6 & 67.9 & 65.3 \\
\hline Cs & n.c. & n.d. & n.d. & n.d. & $<0.20$ & n.d. & n.d. & n.d. \\
\hline Th & 3.0 & 2.9 & 2.7 & 3.1 & 5.6 & 3.5 & 3.8 & 3.7 \\
\hline $\mathrm{La}$ & 44.9 & 14.9 & 36.0 & 39.1 & 40.5 & 62.0 & 47.7 & 60.7 \\
\hline $\mathrm{Ce}$ & 103.0 & 30.4 & 78.7 & 80.7 & 85.7 & 128.0 & 80.9 & 124.0 \\
\hline $\mathrm{Nd}$ & 58.6 & 18.4 & 44.7 & 63.1 & 47.1 & 64.0 & 44.2 & 56.9 \\
\hline Sm & 14.80 & 6.84 & 9.54 & 16.80 & 10.70 & 13.70 & 6.21 & 11.10 \\
\hline Eu & 1.63 & 2.53 & 2.35 & 3.45 & 4.61 & 1.86 & 0.77 & 1.95 \\
\hline $\mathrm{Gd}$ & 6.73 & 8.72 & 8.95 & 7.45 & n.d. & 7.65 & 4.86 & 4.90 \\
\hline $\mathrm{Tb}$ & 0.80 & 0.95 & 1.21 & 1.18 & 1.32 & 0.92 & 0.45 & 0.50 \\
\hline $\mathrm{Yb}$ & 2.55 & 2.07 & 2.91 & 2.21 & 1.80 & 1.53 & 1.49 & 1.04 \\
\hline $\mathrm{Lu}$ & 0.33 & 0.18 & 0.48 & 0.28 & 0.22 & 0.19 & 0.16 & 0.13 \\
\hline$(\mathrm{La} / \mathrm{Yb})_{\mathrm{N}}$ & 11.6 & 4.8 & 8.2 & 11.7 & 14.9 & 26.8 & 21.1 & 38.5 \\
\hline $\mathrm{CIW}^{\mathrm{b}}$ & 96 & 95 & 88 & 95 & 98 & 89 & 95 & 99 \\
\hline
\end{tabular}

n.d. = not determined

a Total $\mathrm{Fe}$ as $\mathrm{FeO}$.

${ }^{\mathrm{b}} \mathrm{CIW}$ (weathering index) $=\left[\mathrm{Al}_{2} \mathrm{O}_{3} /\left(\mathrm{Al}_{2} \mathrm{O}_{3}+\mathrm{CaO}+\mathrm{Na}_{2} \mathrm{O}\right)\right] \times 100$ (molecular proportions) Harnois, 1988$)$.

University of Western Ontario. Ten major and eleven trace elements were analyzed by X-ray fluorescence spectroscopy (XRF) following the methods suggested by Norrish and Hutton (1969) and Feather and Willis (1976). Spectral interferences were corrected from pre-calculated 


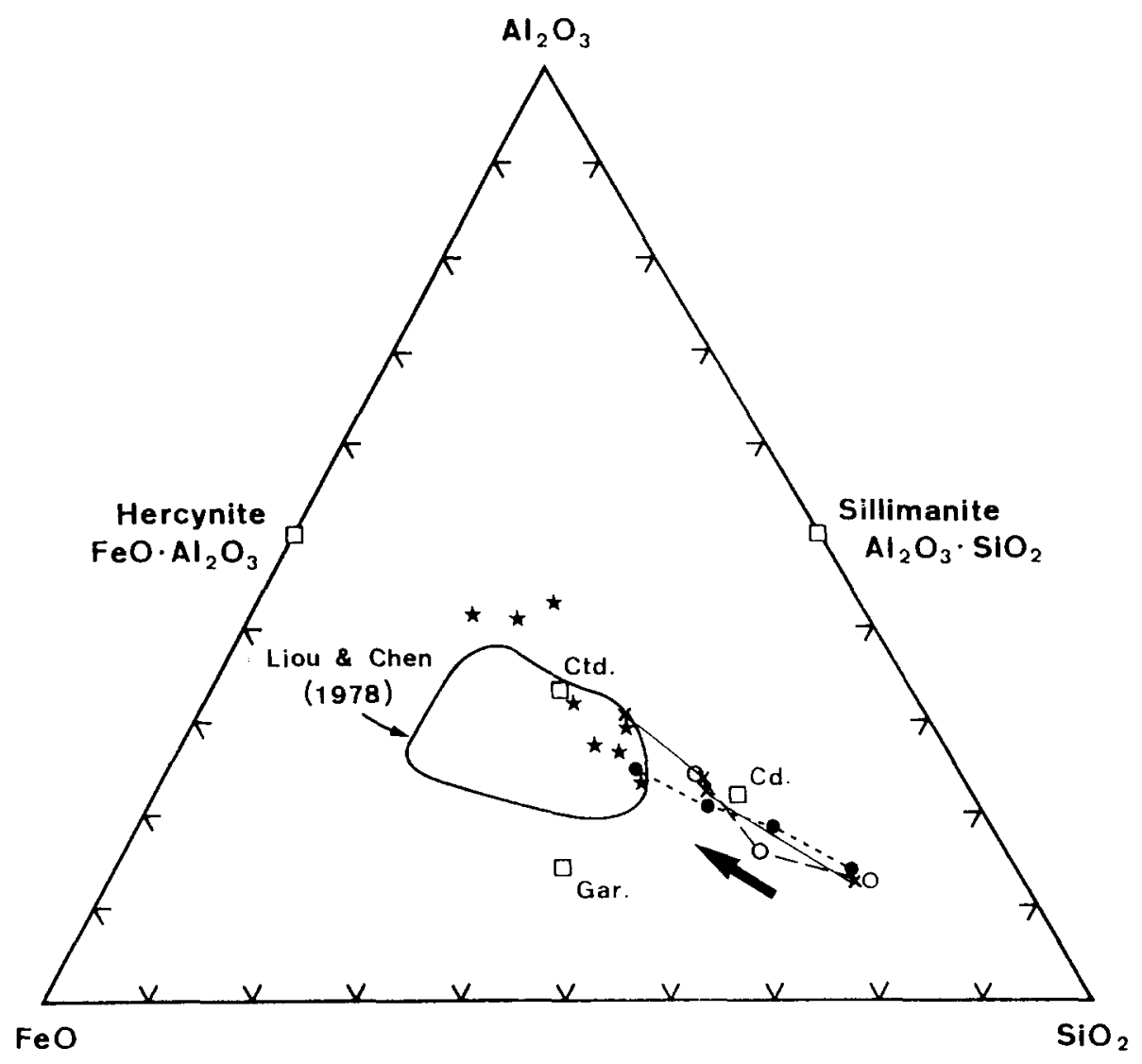

Fig. 2. $\mathrm{Al}_{2} \mathrm{O}_{3}-\mathrm{FeO}-\mathrm{SiO}_{2}$ diagram showing the compositions of the rocks in the present study. Gar.=garnet; $\mathrm{Ctd}$.=chloritoid; $C d .=$ cordierite. Also shown for comparison is the compositional field of the chloritoid-rich rocks reported by Liou and Chen (1978). Closed circles =sequential samples from the LI profile; open circles=sequential samples from the P profile; crosses $=$ sequential samples from the LII profile; stars =chloritoid-rich rocks. Large arrow shows the chemical variation trend from metabasite to garnet-chloritoid rock. See text for details.

interfering factors. In general, the precision was better than $\pm 5 \%$ for all major-element determinations, and $\pm 10 \%$ for most trace-element analyses. The REE's (rare-earth elements), Ta, Hf, $\mathrm{Sc}, \mathrm{Cs}$ and $\mathrm{Th}$, were analyzed by the instrumental neutron activation analysis (INAA) method as described by Gibson and Jagam (1980). Analysis of gamma-ray spectra was done by SAMPO $^{\circ}$ computer program (Routti, 1969). The reproducibility was better than $\pm 5 \%$ for $\mathrm{Sm}, \mathrm{Eu}$, $\mathrm{Ta}, \mathrm{Sc}$ and $\mathrm{Cs}$, but $\pm 10 \%$ for $\mathrm{Ce}, \mathrm{Gd}, \mathrm{Tb}, \mathrm{Yb}, \mathrm{Lu}$, Hf and Th, and $\pm 15 \%$ for La and Nd. The results for the sequential samples from the three profiles at locality 8 are shown in Table 1 , while those for the chloritoid-rich rocks from other lo- calities are presented in Table 2. In both tables, the total iron is expressed as FeO. Owing to the reducing environment of metamorphism, the iron is mainly present as ferrous ion allocated in chloritoid, almandine garnet and ilmenite in the garnet-chloritoid rocks, although magnetite was also reported in the chloritoid-rich rocks (Liou and Chen, 1978).

As shown in Table 1, the compositions of the sequential samples show gradational systematic changes, i.e. from metabasite to garnet-chloritoid rock, $\mathrm{Ti}, \mathrm{Al}, \mathrm{Fe}, \mathrm{K}$, and most of the trace elements increase progressively, whereas $\mathrm{Si}, \mathrm{Mg}$ and $\mathrm{Ca}$ decrease significantly. In the $\mathrm{SiO}_{2}-\mathrm{Al}_{2} \mathrm{O}_{3}-$ FeO diagram (Fig. 2), the $\mathrm{Al}_{2} \mathrm{O}_{3}-\mathrm{FeO}$ enrich- 

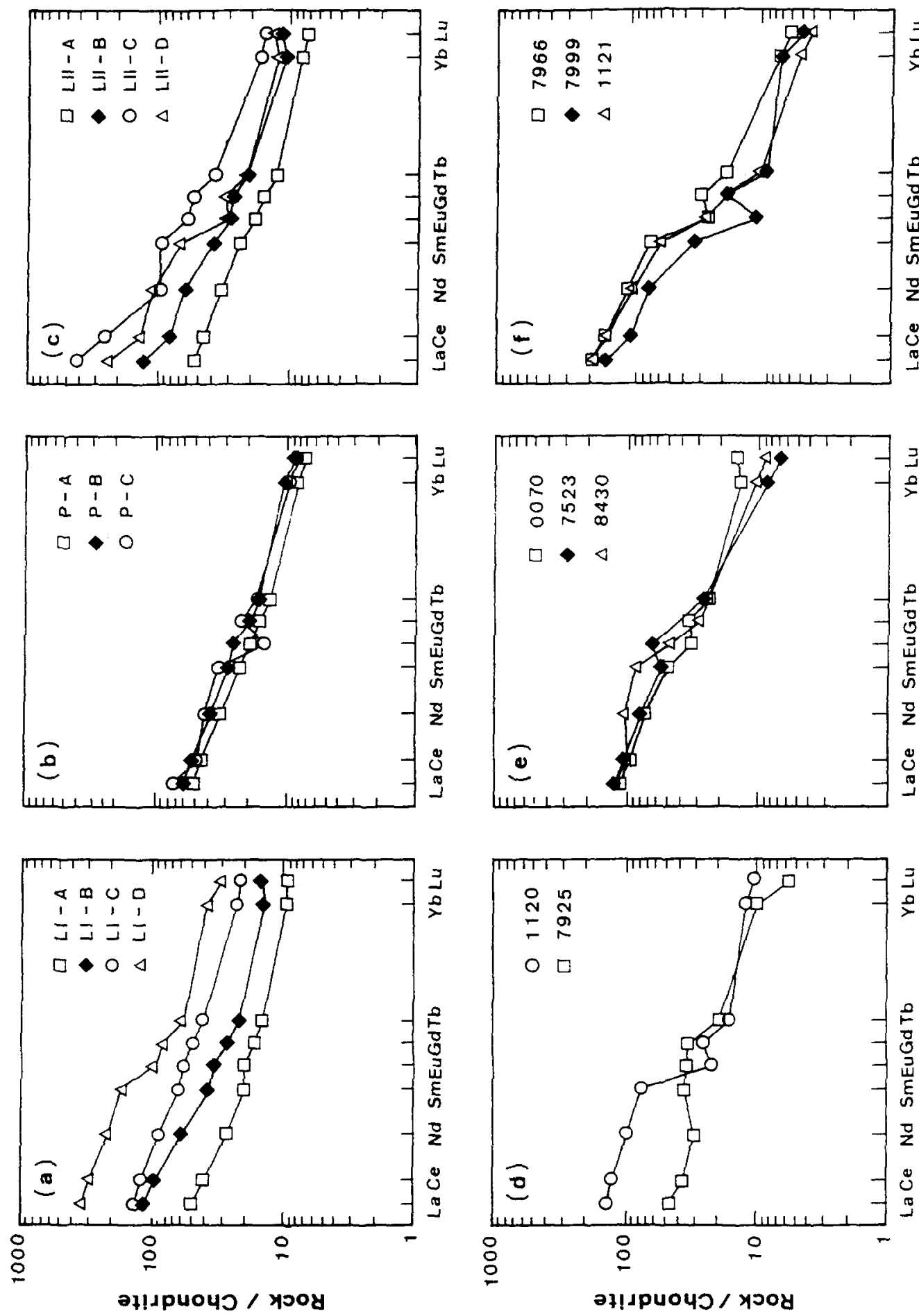

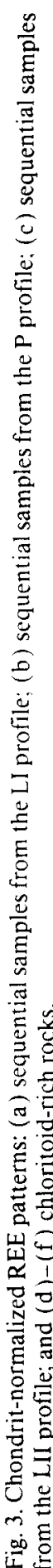


ment trend is evident. In comparison, the chemical compositions of the chloritoid-rich rocks in the present study (Table 2) are similar to those reported by Liou and Chen (1978) (Fig. 2). In the $\mathrm{SiO}_{2}-\mathrm{Al}_{2} \mathrm{O}_{3}-\mathrm{FeO}$ diagram, both the chloritoid-rich rock and the garnet-chloritoid rock are enriched in $\mathrm{Al}$ and $\mathrm{Fe}$ relative to the metabasite, but the former shows more prominent $\mathrm{SiO}_{2}$ depletion (Fig. 2).

The chondrite-normalized REE patterns for these samples are presented in Fig. 3. The metabasites (samples LI-A, P-A and LII-A) are enriched in the light REE's (LREE's), similar to other metabasites in the Tananao Metamorphic Complex reported by Yui et al. (1990a). The garnet-chloritoid rocks are higher in the REE concentrations, more enriched in the LREE's and sometimes exhibit negative $\mathrm{Eu}$ anomaly. The chloritoid-rich rocks display similar REE characteristics, except that they do also show positive Eu anomaly occasionally (Fig. 3d-f).

Even though the rocks in the present study were metamorphosed under greenschist-/amphibolite-facies conditions, the chemical compositions, except the LOI content, of the metabasites are still similar to those of the present-day unaltered basalts (BVSP, 1981). The compositions of the metabasites are also rather homogeneous (Table 1). It is, therefore, assumed that the metamorphism was mainly an isochemical process with respect to the non-volatile components.

\section{Discussion}

Chloritoid is relatively uncommon in low- to medium-grade metamorphic rocks and is restricted to special bulk-rock compositions ( Halferdahl, 1961; Hoschek, 1967). Halferdahl (1961) gave a very detailed compilation about the occurrence of the chloritoid-bearing rocks. Based on his work, chloritoid may occur in hornfelsed pelitic schists, in emery deposits, in hydrothermally altered rocks/hydrothermal veins and in regionally metamorphosed pelitic sediments, particularly those rich in $\mathrm{Al}$ and $\mathrm{Fe}$, but poor in $\mathrm{Ca}, \mathrm{Mg}, \mathrm{K}$ and $\mathrm{Na}$. In low-grade metamorphic rocks, chloritoid is usually accom- panied by quartz, chlorite, muscovite, corundum, diaspore, calcite, rutile and/or iron oxide. In higher-grade rocks, almandine, staurolite and kyanite are common associates. The protoliths of these rocks could be (altered) basalt, (altered) shale and residual deposits (or their sedimentary equivalents) (e.g., Halferdahl, 1961; Hoschek, 1967; Iwao, 1978; La Tour et al., 1980; Phillips, 1988; Palmer et al., 1989a). Since the protoliths cover a wide variety of rocks, the chemical compositions of the chloritoid-bearing rocks vary considerably. For example, their silica content may vary from nearly zero to $\sim 90$ wt\% (Halferdahl, 1961). Despite such component variations, some characteristic chemical features do exist for the chloritoid-bearing rocks, e.g., more alumina than the total mafic oxides; an excess of alumina after calculating $\mathrm{K}_{2} \mathrm{O}, \mathrm{Na}_{2} \mathrm{O}$ and $\mathrm{CaO}$ as micas, plagioclase or epidote; more $\mathrm{FeO}+\mathrm{MnO}$ than $\mathrm{MgO}$; and more $\mathrm{FeO}+\mathrm{MnO}$ than $\mathrm{Fe}_{2} \mathrm{O}_{3}$ (Halferdahl, 1961). Hoschek (1967) also concluded that to contain chloritoid, rocks should simultaneously meet the following chemical criteria: low abundances of alkalis and $\mathrm{CaO}$; $\left(\mathrm{FeO}^{*}+\mathrm{MgO}\right) /\left(\mathrm{FeO}^{*}+\mathrm{MgO}+\mathrm{Al}_{2} \mathrm{O}_{3}\right)<0.63$ and $\mathrm{FeO}^{*} /\left(\mathrm{FeO}^{*}+\mathrm{Al}_{2} \mathrm{O}_{3}\right)<0.58$. The garnetchloritoid and chloritoid-rich rocks in the present study are relatively low in silica content (Tables 1 and 2), compared to the normal shales and basalts. Most samples do have low alkali and $\mathrm{CaO}$ contents and show chemical characteristics compatible with those documented by Halferdahl (1961) and within the chemical limitations postulated by Hoschek (1967). Some samples (e.g., samples LI-B and PI-B in Table 1), however, exhibit relatively high $\mathrm{Fe}-\mathrm{Mg}$ contents that do not concur with Hoschek's chemical limitations. In studying the chloritoid-bearing metabasite, La Tour et al. (1980) reported bulk-rock chemical compositions with very high Fe content and suggested that the chemical limitations proposed by Hoschek (1967) may not be valid since the presence of accessory minerals, such as magnetite and ilmenite, could accommodate excess Fe.

The similar high $\mathrm{Al}$ and $\mathrm{Fe}$ contents in the garnet-chloritoid and chloritoid-rich rocks in the present study are significant. These rocks with similar chemical characteristics but with differ- 
ent metamorphic grades suggest that their distinct bulk compositions were largely developed either prior to metamorphism or in the early stages of their metamorphic history. This is consistent with the suggestion made by Liou and Chen (1978) that these Al-Fe-rich rocks could be of lateritic origin derived from a basaltic layer. Therefore, the observed gradational chemical changes along the three profiles at locality 8 may have most likely resulted from weathering. However, Schreyer et al. (1981), Phillips (1988) and Palmer et al. (1989a) argued that hydrothermal alteration, either caused by pre-metamorphic postvolcanic exhalative processes or by synmetamorphic hydrothermal processes, could also produce rocks with high $\mathrm{Al}$ content in metamorphic terrains. Although it is difficult to distinguish the pedogenic vs. hydrothermal origins for the Al-Fe-rich rocks based solely on the chemical data (e.g., Retallack, 1989), the latter proposition is discounted in the present study since any hydrothermal alteration should not restrict its effects only to the garnet-chloritoid/chloritoid-rich rocks or to the top of the lava flows. The regional distribution of the Al-Fe-rich rocks in the present study as two parallel belts mentioned above does not favor a hydrothermal origin either. Although the granitic gneiss intruded the marble-metabasite rock association in the study area, the present contact is largely tectonic. No contact metamorphism or hydrothermal alteration is observed around the granitic gneiss.

The composition-volume changes of weathering profiles could be quantitatively analyzed by a series of equations as proposed by Gresens (1967). However, a simple "isocon diagram" as a solution to Gresens' equations was provided by Grant (1986). Fig. 4, then, employs Grant's method for sequential samples that were collected from the lower lava flow (LI) unit. The metabasite sample, LI-A, in this profile is assumed to be the least altered and its composition may closely represent that of the igneous precur-

Fig. 4. Isocon diagram for samples from the LI profile. Solid line = constant $\mathrm{Ti}$ and $\mathrm{Zr}$; long-dashed line=constant mass; short-dashed line $=$ constant volume. See text for more details.

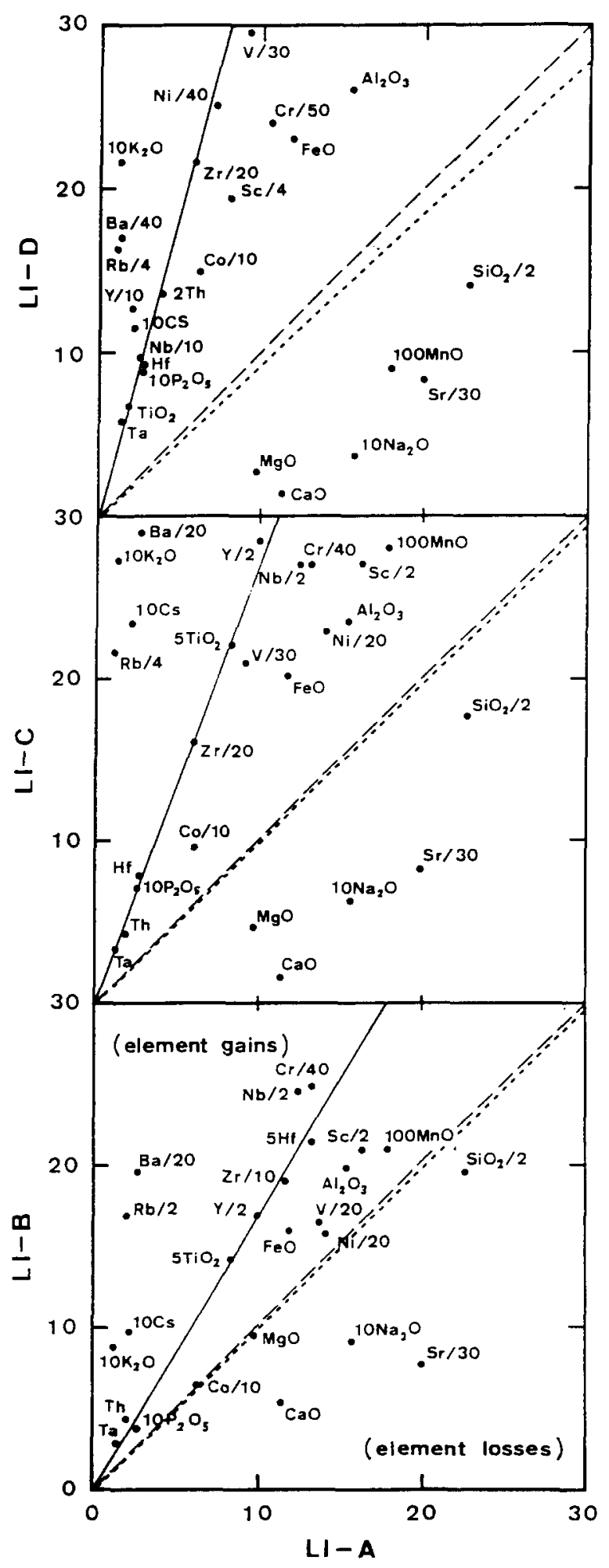


sor. The composition of each element, multiplied by a proper scaling factor, was plotted in the figure for successive samples. As pointed out by Grant (1986), elements that remain immobile should fall on a single straight line passing through the origin. Such a line is called an "isocon". Elements that were truly immobile throughout the profile should define isocons in each diagram in Fig. 4, although the slope of the isocon may change from sample to sample. Careful inspection of Fig. 4 shows that only $\mathrm{Ti}$ and $\mathrm{Zr}$ can be closely fitted to isocons throughout the profile. This result is consistent with the conventional knowledge that these two elements are generally considered to be immobile during weathering/metamorphism. Elements which fall to the right/left of the isocon represent losses/ gains, respectively, relative to $\mathrm{Ti}$ and $\mathrm{Zr}$. Note that although the chemical compositions of the sequential samples show apparent progressive $\mathrm{Al}$ and $\mathrm{Fe}$ enrichment in Table 1 , these two elements are actually leached (Fig. 4). Only K, Rb, $\mathrm{Cs}$ and $\mathrm{Ba}$ were consistently enriched throughout. The densities of samples LI-A, -B, -C and $\mathrm{D}$ are $3.132,3.168,3.172$ and $3.397 \mathrm{~g} \mathrm{~cm}^{-3}$, respectively. Calculations yield integrated (including weathering and metamorphic effects) mass losses of $38 \%, 64 \%$ and $73 \%$, and volume decreases of $39 \%, 65 \%$ and $75 \%$ for samples LIB, - C and $-D$, respectively.

Similar features also hold for the pillow lava profile and the upper lava flow profile at locality 8 , although the relevant isocon diagrams are not shown. To give a clearer and more quantitative idea, the percent change of each element (X) relative to the least altered rock vs. the degree of weathering along the profiles is shown in Figs. 5 and 6 for major and trace elements, respectively. The percent change is calculated assuming Ti remains constant:

(percent change $)=$

$$
\left(\frac{(\mathrm{X} / \mathrm{Ti})_{\text {sample }}}{(\mathrm{X} / \mathrm{Ti})_{\text {least altered rock }}}-1\right) \times 100
$$

The degree of weathering is measured by the weathering index (CIW) as defined by Harnois (1988):

$$
\begin{aligned}
\mathrm{CIW}= & {\left[\mathrm{Al}_{2} \mathrm{O}_{3} /\left(\mathrm{Al}_{2} \mathrm{O}_{3}+\mathrm{CaO}+\mathrm{Na}_{2} \mathrm{O}\right)\right] } \\
& \times 100 \quad \text { (molecular proportions) }
\end{aligned}
$$

It is noted that the upper lava flow is overlain by marble. Field observations show that the garnet-chloritoid rocks developed on this unit might have been contaminated by some carbonate clasts. This is manifested by the progressive increase in $\mathrm{CaO}$ content (or epidote content in mineralogy) for the garnet-chloritoid rocks (LIIB, -C and -D in Table 1). The calculated CIW for this profile, therefore, may be a little misleading.

As shown in Fig. 5, $\mathrm{Si}, \mathrm{Mn}, \mathrm{Mg}, \mathrm{Ca}, \mathrm{P}$, and to a lesser extent, $\mathrm{Al}$ and $\mathrm{Fe}$, are progressively depleted as CIW increases in all three profiles. $\mathrm{Na}$ behaves a little differently in the LII profile, probably an apparent feature due to the very low Na content in sample LII-A (Table 1). K, however, is significantly enriched. Trace elements $\mathrm{Nb}, \mathrm{Ta}$ and $\mathrm{Hf}$, in addition to $\mathrm{Zr}$, also remain relatively constant, but $(\mathrm{V}, \mathrm{Cr})<\mathrm{Zn}<(\mathrm{Sc}, \mathrm{Co})<\mathrm{Ni}<\mathrm{Sr}$ (in this order of increasing mobility) decrease successively. $Y$ and Th either increase or decrease, while $\mathrm{Rb}, \mathrm{Cs}$ and Ba show prominent increases (Fig. 6).

The chloritoid-rich rocks from localities $1-7$ occur as thin pods or lenses in the well-foliated chloritoid-bearing greenschist. Compared with the metabasites, the chemical compositions of the chloritoid-bearing greenschist show different, albeit small degrees of $\mathrm{Al}-\mathrm{Fe}-\mathrm{Ti}$ enrichment (Liou and Chen, 1978). Gradational changes from parental rocks to chloritoid-rich rocks, like those in locality 8 , cannot be observed. Similar data comparisons to those discussed for the three profiles from locality 8 are not possible. However, if the parent rocks (i.e. the metabasites) in the study area all exhibit similar chemical characteristics, as documented by Yui et al. (1990a), the largest contrasting feature between the chloritoid-rich rocks and the garnet-chloritoid rocks would be that the former show significantly lower abundances of $\mathrm{K}, \mathrm{Rb}, \mathrm{Cs}$ and $\mathrm{Ba}$ for rocks with a comparable weathering index (Tables 1 and 2 ).

The element mobility during weathering is a function of many variables, such as the stability of the primary minerals, the chemical composi- 

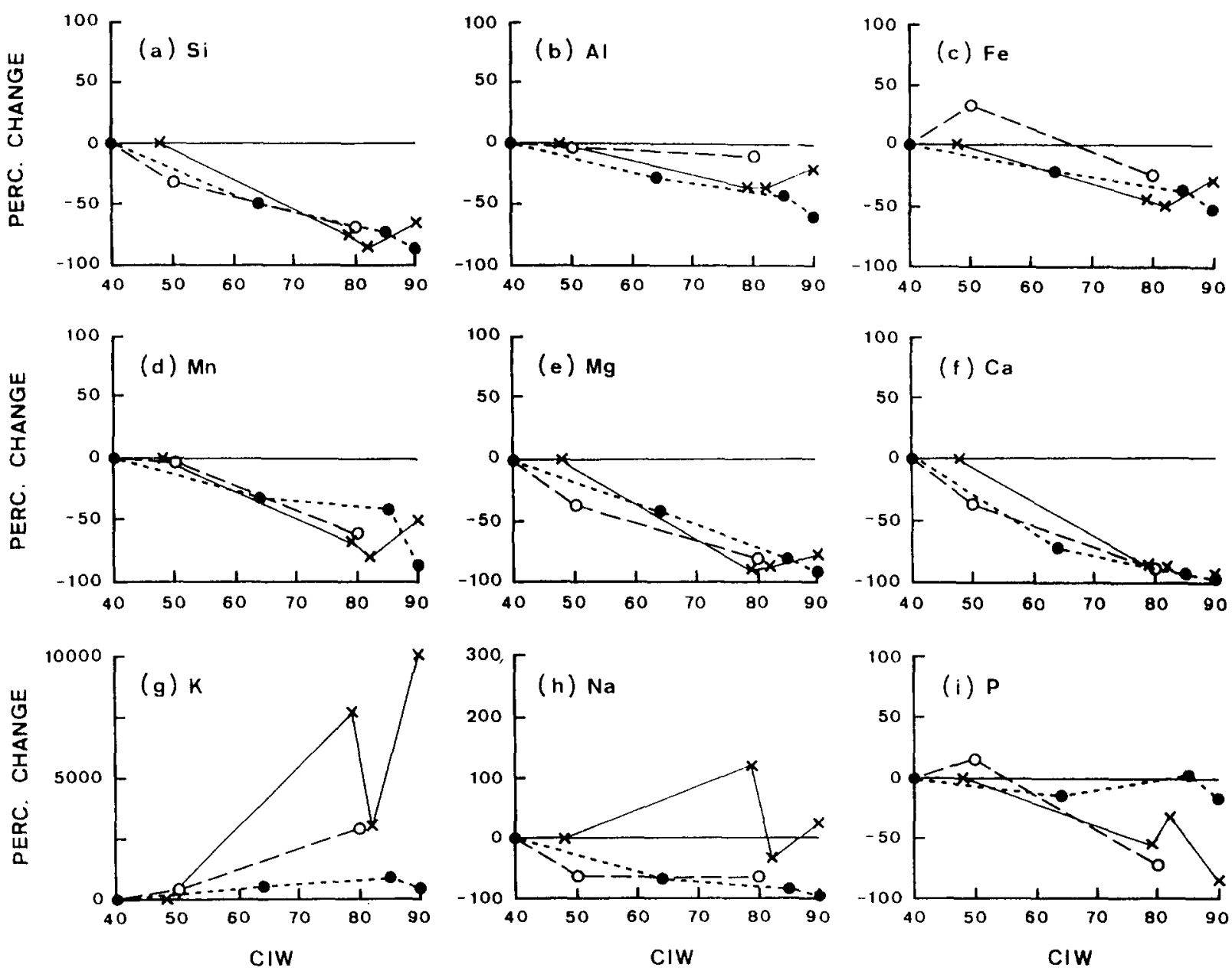

Fig. 5. Percent change, normalized with respect to Ti, of major elements vs. the weathering index (CIW). Note the vertical scales in $(\mathrm{g})$ and $(\mathrm{h})$. Closed circles $=$ sequential samples from the $\mathrm{LI}$ profile; open circles = sequential samples from the P profile; crosses $=$ sequential samples from the LII profile.

tion and the surface properties of the secondary minerals, the compositions of the fluid phase, the topography as well as the local Eh-pH environment (e.g., Fritz and Ragland, 1980; Nesbitt et al., 1980; Cramer and Nesbitt, 1983; Fritz and Mohr, 1984; Middelburg et al., 1988). Despite these complexities, studies on the weathering of basalts under subaerial conditions generally show distinct $\mathrm{K}, \mathrm{Rb}, \mathrm{Cs}$ and $\mathrm{Ba}$ depletion (e.g., Furnes, 1978; Chesworth et al., 1981; Colman, 1982; Noack et al., 1990; Marsh, 1991), similar to the weathering results of other rock types (e.g., Goldlich, 1938; Nesbitt et al., 1980; Minarik et al., 1983; Kronberg et al., 1987; Middelburg et al., 1988; Nesbitt and Young, 1989). The chemical characteristics of the chloritoid-rich rocks are, thus, consistent with the postulate that they are of lateritic origin (Liou and Chen, 1978). The $\mathrm{K}, \mathrm{Rb}, \mathrm{Cs}$ and $\mathrm{Ba}$ enrichment for the garnetchloritoid rocks, on the other hand, requires an alternative explanation.

The anomalous $\mathrm{K}$ enrichment in weathering profiles is not uncommon. It was reported for the paleo-weathering profiles of Paleozoic age (Wahlstrom, 1948; Retallack, 1985; Krois et al., 1990 ) as well as those of Precambrian age (Wil- 

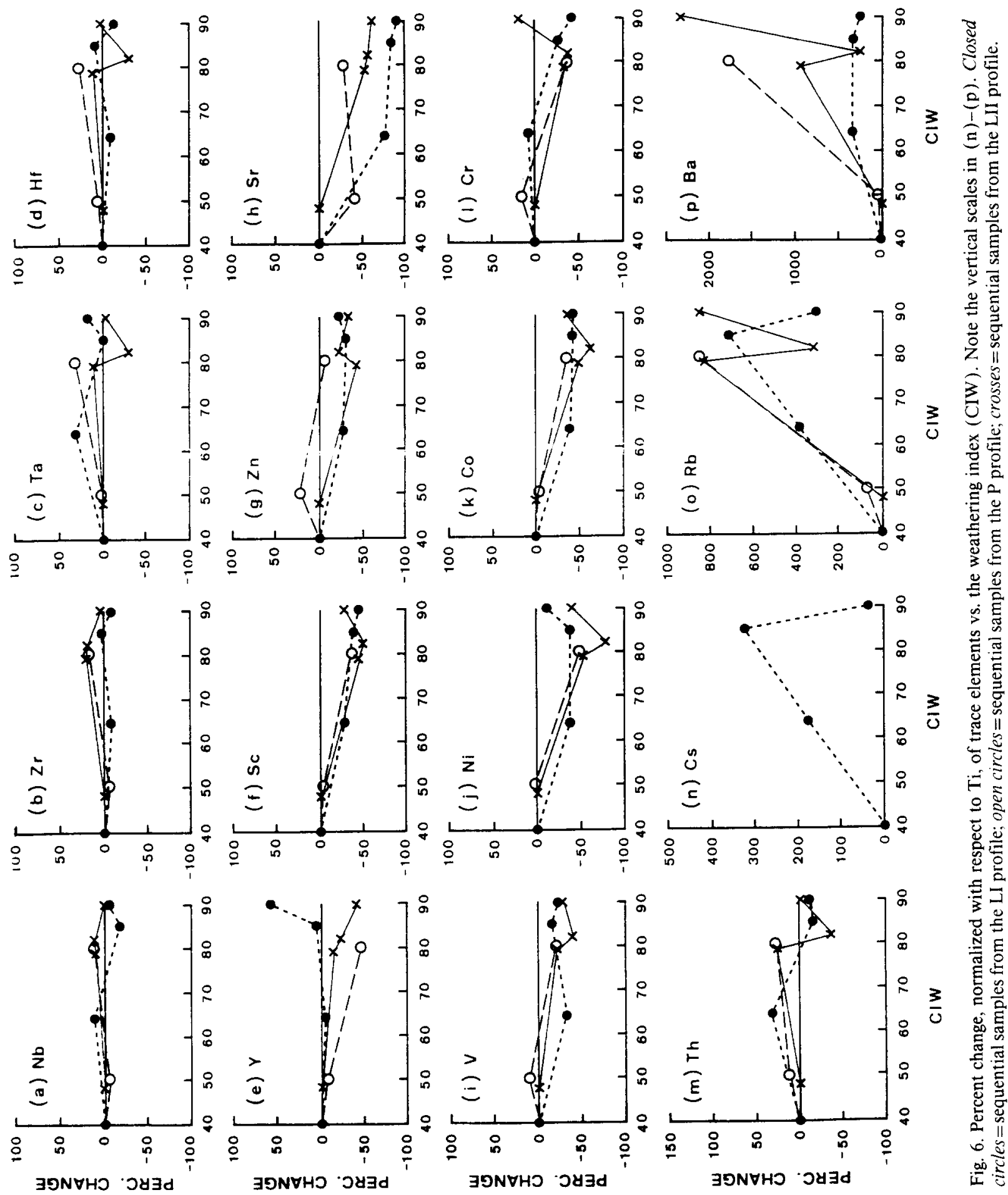

吾 
liams, 1968; Button, 1979; Gay and Grandstaff, 1980; Sokolov and Hieskanen, 1984; Palmer et al., 1989a; Holland et al., 1990; Rainbird et al., 1990; Sutton and Maynard, 1991). Retallack (1986) postulated that such an anomalous K enrichment most probably originated from burial diagenesis of the weathering horizon. Based on kinetic, thermodynamic and mass-balance considerations, Nesbitt and Young (1989) concluded that the chemical changes of the weathering profiles are predictable, and they also favored the suggestion that diagenesis in continental environments may account for such $\mathrm{K}$ enrichment in some paleo-weathering horizons, although external K sources are needed. Such external $\mathrm{K}$ was usually attributed to diagenetic fluid which had equilibrated with K-feldspar in the overlying clastic sediments and percolated downward (e.g., Zbinden et al., 1988; Retallack, 1989). However, this postulate may not be applicable in the present case. The rocks which overlie the present weathering profiles are marbles, rather than metamorphosed clastic rocks. In fact, the former do not contain any $\mathrm{K}$ minerals. From the mass-balance point of view, if the upper $30 \mathrm{~cm}$ of the LI profile in this study have an averaged $\mathrm{K}_{2} \mathrm{O}$ content of $2.45 \%$ with a volume decrease of $70 \%$ and if the $K$ content of the groundwater in the basaltic rock and limestone area is assumed to be $\sim 1-7 \mathrm{ppm}$ (White et al., 1963 ), then rough calculations would result in an unreasonable integrated water/rock mass ratio of $\sim 2,000-20,000$ during diagenesis to account for the observed $\mathrm{K}$ enrichment. This ratio could be reduced if the diagenetic fluid had an abnormal $\mathrm{K}$ content. However, since both the garnet-chloritoid rocks and the chloritoid-rich rocks in the study area might have experienced a similar post-weathering geohistory, it seems implausible to assume that only the garnet-chloritoid rocks suffered from such K enrichment during diagenetic reactions. Although the garnetchloritoid rocks were subjected to slightly higher metamorphic $P-T$ conditions than the chloritoid-rich rocks (i.e. the amphibolite facies vs. the greenschist facies), this difference should not be responsible for such a chemical contrast either.

The association with marble as well as the pil- low structure of the metabasite at locality 8 demonstrate that the basalt was probably emplaced in a shallow submarine environment. Low-temperature seawater-basalt interaction (i.e. submarine weathering) causes complicated chemical changes of basalts under variable environments (Honnorez, 1981 and references therein). In spite of the complexities, such reactions almost invariably cause significant $\mathrm{K}, \mathrm{Rb}$ and $\mathrm{Cs}$ enrichment in weathered basalts. $\mathrm{Ba}$ enrichment is not uncommon either. Altered basalts from Hole 417A [International Phase of Ocean Drilling (IPOD) Legs 50,51 and 52] at the southern end of the Bermuda Rise in the North Atlantic even exhibit an apparent $\mathrm{K}_{2} \mathrm{O}$ content of up to 6\% (Donnelly et al., 1979), which was suggested to be the result of 10-20Ma seawater-basalt interaction. Bienvenu et al. (1990) likewise reported one altered basalt sample which, having been exposed on the seafloor for $\sim 35 \mathrm{Ma}$, showed significant apparent depletion in $\mathrm{Si}, \mathrm{Mg}$ and $\mathrm{Ca}$, and enrichment in $\mathrm{Fe}, \mathrm{Ti}$, $\mathrm{K}, \mathrm{Rb}$ and $\mathrm{Cs}$. These chemical changes are, in fact, similar to the chemical characteristics of the profiles discussed previously in this paper. Though the tectonic setting may not be the same, the above examples and the field occurrence of the garnet-chloritoid rocks, i.e. on top of the lava flows and around the pillows, do indeed show that a long-term submarine weathering may have been the cause for most, if not all, of the chemical changes observed along the three profiles at locality 8 of this study.

The chloritoid-rich rocks at localities 1-7 might also have experienced similar submarine weathering processes. If so, the submarineweathering chemical signatures must have largely been erased by later subaerial processes, which could also explain why the protoliths of the chloritoid-rich rocks are more mature (i.e. more Al-Fe-enriched and Si-depleted, see Fig. 2) than those of the garnet-chloritoid rocks.

Most of the paleosols of Paleozoic/Precambrian age with anomalous $\mathrm{K}$ enrichment were either developed on basaltic rocks/greenstones or covered by marine clastic sediments (e.g., Button, 1979; Holland et al., 1990; Krois et al., 1990; Sutton and Maynard, 1991). Like the present 
study, the submarine-weathering process should be considered/explored as one of the possible causes responsible, or partially responsible, for the $\mathrm{K}$ enrichment. This mechanism overcomes the cumbersome mass-balance problem which results when considering the external $\mathrm{K}$ sources required in the continental diagenetic model (Nesbitt and Young, 1989).

The percent change of the REE's vs. atomic number for the three profiles from locality 8 are shown in Fig. 7a-c. Combined with the chondrite-normalized pattern (Fig. 3), the following features are most distinct: (1) the LREE's were enriched, whereas the heavy REE's (HREE's) were leached from the two lava-flow profiles; (2) the REE's were all leached from the pillow profile; (3) preferential leaching as well as accumulation of the Eu were observed; and (4) a marked negative $\mathrm{Ce}$ anomaly in the chondrite-normalized pattern, a common feature for weathered submarine basalts, was not observed in the present study.

Since the REE systematics are generally not thought to be affected by metamorphism (e.g., Bau, 1991), the above features are ascribed to low-temperature seawater-basalt interactions. The mobility of the REE's during submarine weathering of basalts depends on the environment, in particular the water/rock ratio and the duration of interaction time. Both the uptake of the LREE's and the leaching of all REE's were reported previously (Frey et al., 1974; Ludden and Thompson, 1978; Staudigel et al., 1979; Staudigel and Hart, 1983). The uptake of the LREE's was attributed to a high water/rock ratio, long exposure time, and, hence, equilibration with seawater. Under the opposite conditions, all REE's were leached. Equilibration with seawater was also invoked to explain the negative $\mathrm{Ce}$ anomaly observed in some weathered submarine basalts (Frey et al., 1974; Robertson and Fleet, 1976; Ludden and Thompson, 1979; Humphris, 1984). However, if seawater, e.g., shallow seawater, does not exhibit a negative Ce anomaly (Shimizu and Masuda, 1977), then neither would the weathered basalts. The preferential removal of HREE's from the basalts is not uncommon and might be due to the fact that
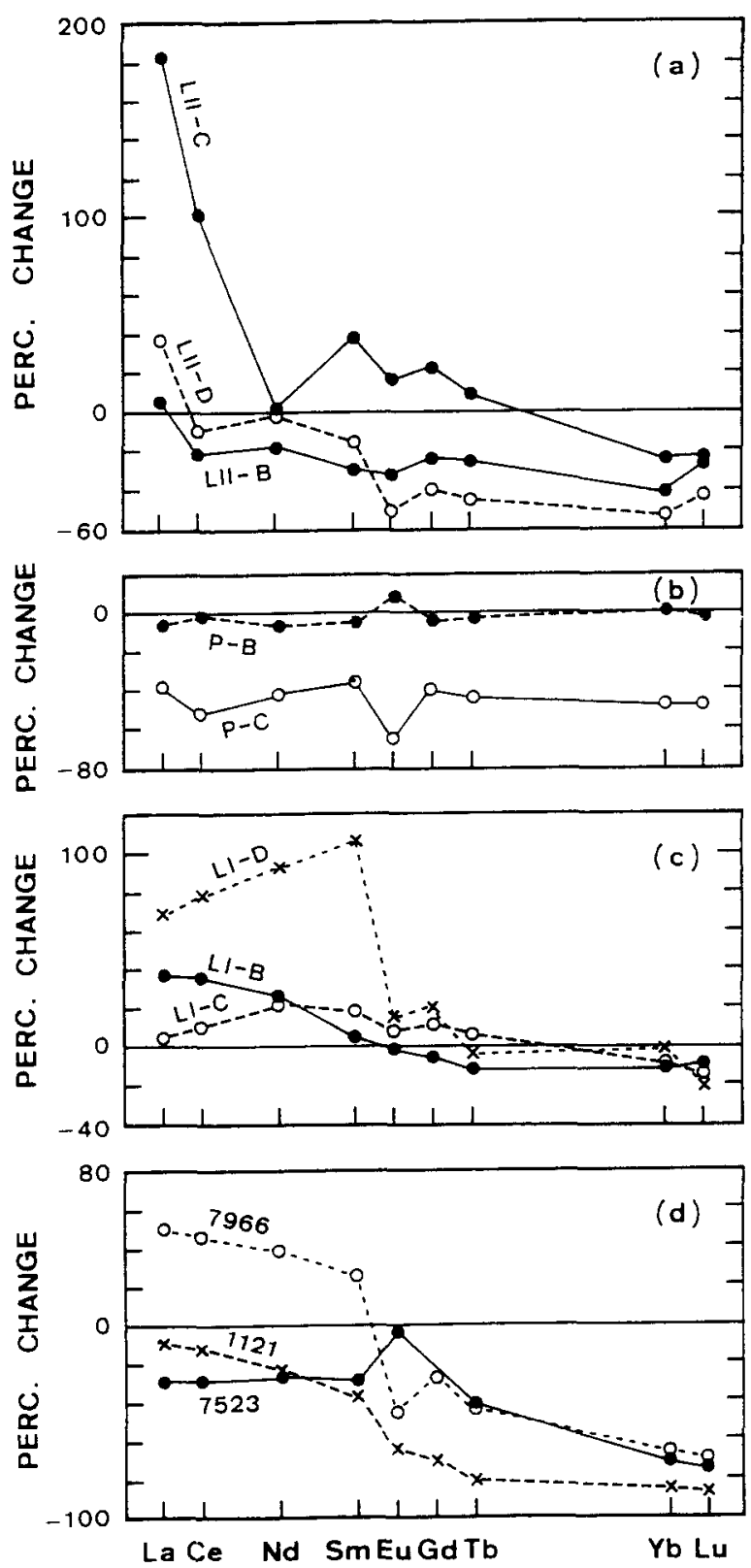

Fig. 7. Percent change, normalized with respect to Ti, of REE's vs. atomic number: (a) sequential samples from the LI profile; (b) sequential samples from the P profile; (c) sequential samples from the LII profile; and (d) representative samples for the chloritoid-rich rocks.

they may have formed more soluble ionic complexes than the LREE's in seawater. This relative mobility, nevertheless, is also a function of $\mathrm{pH}$ (Cantrell and Byrne, 1987; Brookins, 1989). The 
observed REE characteristics of the three profiles, thus, demonstrate heterogeneous weathering environments.

Both preferential leaching and accumulation of Eu were observed in the profiles. Since under weathering conditions, Eu should be dominantly in the trivalent state in aqueous fluids and not be fractionated from other REE's (Sverjensky, 1984; Brookins, 1989), the observed anomalous Eu behavior can only be accounted for by mineralogical controls. Significant alteration of plagioclase may be the reason for the preferential leaching of $\mathrm{Eu}$ in more severely weathered samples (Fig. $7 \mathrm{a}-\mathrm{c}$ ). In the pillow-lava profile, although the REE's were mainly leached, the two altered samples show almost mirror-imaged REE percent change patterns, especially Eu (Fig. 7b). Due to changes in $\mathrm{pH}$ as the weathering fluid percolated through the pillow lava, partial precipitation/adsorption of the REE's, leached from the more weathered pillow rind (sample PI-C) on the less weathered portion (sample PI-B), may explain this observation. A similar phenomenon was reported by Nesbitt (1979) from a weathering profile developed on Australian granodiorite.

Assuming the protoliths of the chloritoid-rich rocks have similar REE compositions to those of the metabasites from locality 8 , representative percent change of REE plots are shown in Fig. 7d. Similar features to those of the garnet-chloritoid rocks are also observed, except that only one sample (sample 7966) shows LREE enrichment. This may be accounted for by the superimposed effect of the inferred subaerial processes.

\section{Conclusions}

The metamorphosed Al-Fe-rich rocks in the Tananao Metamorphic Complex of Taiwan may be indicative of paleo-weathering horizon (s) developed on basaltic rocks. These rocks form two belts parallel to the main foliation trend of the complex. Such spatial distribution demonstrates the possible potential of these rocks to serve as a stratigraphic indicator in this structurally complicated metamorphic terrain.
These Al-Fe-rich rocks have been metamorphosed under different conditions, leading to different mineral assemblages: the garnet-chloritoid rocks of the amphibolite facies (locality 8 ) and the chloritoid-rich rocks of the greenschist facies (localities 1-7). The chemical characteristics, as well as the field occurrences of the chloritoid-rich rocks, indicate a lateritic origin. In contrast, three profiles from metabasite to garnet-chloritoid rock, developed either on lava flows or around pillows, show distinct $\mathrm{K}, \mathrm{Rb}, \mathrm{Cs}$ and $\mathrm{Ba}$ enrichment. $\mathrm{Ti}, \mathrm{Zr}, \mathrm{Nb}, \mathrm{Ta}$ and $\mathrm{Hf}$ remained relatively immobile, while $\mathrm{Si}, \mathrm{Mn}, \mathrm{Mg}$, $\mathrm{Ca}, \mathrm{P}, \mathrm{Al}, \mathrm{Fe}, \mathrm{Sr}, \mathrm{Ni}, \mathrm{Co}, \mathrm{Sc}, \mathrm{Zn}, \mathrm{Cr}$ and $\mathrm{V}$ were all depleted from the garnet-chloritoid rock. It is concluded that all these chemical changes might not have been caused by metamorphism/hydrothermal alteration/diagenesis, but may have largely resulted from submarine weathering. The non-coherent behavior of the REE's also demonstrates heterogeneous submarine weathering environments. The chloritoid-rich rocks might have experienced similar submarine weathering processes but must have later been superimposed by subaerial processes, leading to $\mathrm{K}, \mathrm{Rb}$, $\mathrm{Cs}$ and $\mathrm{Ba}$ depletion and more intensive $\mathrm{Al}-\mathrm{Fe}$ enrichment relative to $\mathrm{Si}$.

$\mathrm{K}$ enrichment is not an unusual feature, especially for those paleosols of Paleozoic/Precambrian age. It is recommended, in addition to the diagenesis in continental environments, that submarine weathering also is to be considered a probable cause.

\section{Acknowledgements}

Part of the financial support for this study was from the Academia Sinica. Helpful discussions with H.W. Yeh, Y.N. Shieh and Y. Li are appreciated. Special thanks go to K. Kump, S. Brantley and an anonymous reviewer for their critical suggestions.

\section{References}

Barrientos, X. and Selverstone, J., 1987. Metamorphosed soils as stratigraphic indicators in deformed terranes: an ex- 
ample from the Eastern Alps. Geology, 15: 841-844.

Bau, M., 1991. Rare-earth element mobility during hydrothermal and metamorphic fluid-rock interaction and the significance of the oxidation state of europium. Chem. Geol., 93: 219-230.

Bienvenu, P., Bougault, H., Joron, J.L., Treuil, M. and Dmitriev, L., 1990. MORB alteration: rare-earth element/nonrare-earth hygromagmaphile element fractionation. Chem. Geol., 82: 1-14.

Birkeland, P.W., Crandell, D.R. and Richmond, G.M., 1971. Status of correlation of Quaternary stratigraphic units in the western conterminous United States. Quat. Res., 1: 208-227.

Brookins, D.G., 1989. Aqueous geochemistry of rare earth elements. In: R.R. Lipin and G.A. McKay (Editors), Geochemistry and Mineralogy of Rare Earth Elements. Rev. Mineral., 21: 201-225.

Button, A., 1979. Early Proterozoic weathering profile on the 2200 m.y. old Hekpoort Basalt, Pretoria Group, South Africa. Geol. Res. Unit, Johannesburg, Info. Circ. No. 133, $19 \mathrm{pp}$.

BVSP (Basaltic Volcanism Study Project), 1981. Basaltic Volcanism on the Terrestrial Planets. Pergamon, New York, N.Y., 1286 pp.

Campbell, I.B., 1986. Recognition of paleosols in Quaternary periglacial and volcanic environments in New Zealand. In: V.P. Wright (Editor), Paleosols, Their Recognition and Interpretation. Princeton University Press, Princeton, N.J., pp. 208-241.

Cantrell, K.J. and Byrne, R.H., 1987. Rare earth element complexation by carbonate and oxalate ions. Geochim. Cosmochim. Acta, 51: 597-605.

Chen, C.H., 1989. A preliminary study of the fossil dinoflagellates from the Tananao Schist, Taiwan. M.S. Thesis, Institute of Geology, National Taiwan University, Taiwan (in Chinese).

Chen, P.Y., 1963. Mineralogy and petrology of the chloritoid rock from Shakatangchi and Laohsichi areas, Hualien, Taiwan. Acta Geol. Taiwanica, 10: 11-27.

Chesworth, W., Dejou, J. and Larroque, P., 1981. The weathering of basalt and relative mobilities of the major elements at Belbex, France. Geochim. Cosmochim. Acta, 45: 1235-1243.

Colman, S.M., 1982. Chemical weathering of basalts and andesites: evidence from weathering rinds. U.S. Geol. Surv., Prof. Pap. No. 1246, 51 pp.

Cramer, J.J. and Nesbitt, H.W., 1983. Mass-balance relations and trace-element mobility during continental weathering of various igneous rocks. Symp. on Petroloty of Weathering and Soils. Sci. Geol., Mem., 73: 63-73.

Donnelly, T., Francheteau, J., Bryan, W., Robinson, P., Flower, M. and Salisbury, M. (Editors), 1979. Initial Reports of Deep Sea Drilling Project, Vols. 51-53, Part 2. U.S. Gov. Print. Off., Washington, D.C., 1613 pp.

Feather, C.E. and Willis, J.P., 1976. A simple method for background and matrix correction of spectral peaks in trace element determination by $\mathrm{X}$-ray fluorescence spectrometry. X-ray Spectrom., 5: 41-48.

Frey, F.A., Bryan, W.B. and Thompson, G., 1974. Atlantic Ocean floor: geochemistry and petrology of basalts from Legs 2 and 3 of the Deep Sea Drilling Project. J. Geophys. Res., 79: 5507-5527.

Fritz, S.J. and Mohr, D.W., 1984. Chemical alteration in the micro weathering environment within a spheroidallyweathered anorthite boulder. Geochim. Cosmochim. Acta, 48: 2527-2535.

Fritz, S.J. and Ragland, P.C., 1980. Weathering rinds developed on plutonic igneous rocks in the North Carolina Piedmont. Am. J. Sci., 280: 546-559.

Furnes, H., 1978. Element mobility during palagonization of a subglacial hyaloclastite in Iceland. Chem. Geol., 22: 249264.

Gay, A.L. and Grandstaff, D.E., 1980. Chemistry and mineralogy of Precambrian paleosols at Elliot Lake, Ontario Canada. Precambrian Res., 12: 349-373.

Gibson, I.L. and Jagam, P., 1980. Instrumental neutron activation analysis of rocks and minerals. In: G.K. Muecke (Editor), Neutron Activation in the Geosciences. Mineral. Assoc. Can., Short Course Handbk., pp. 109-131.

Goldlich, S.S., 1938. A study in rock weathering. J. Geol., 46: $17-58$.

Grant, J.A., 1986. The isocon diagram - a simple solution to Gresens' equation for metasomatic alteration. Econ. Geol., 81: 1976-1982.

Gresens, R.L., 1967. Composition-volume relationships of metasomatism. Chem. Geol., 2: 47-55.

Halferdahl, L.B., 1961. Chloritoid: its composition, X-ray and optical properties, stability, and occurrence. J. Petrol., 2: 49-135.

Harnois, L., 1988. The CIW index: a new chemical index of weathering. Sediment. Geol., 55: 319-322.

Holland, H.D., 1984. The Chemical Evolution of the Atmosphere and Oceans. Princeton University Press, Princeton, N.J., $582 \mathrm{pp}$.

Holland, H.D. and Feakes, C.R., 1989. Paleosols and their relevance to Precambrian atmospheric composition: a discussion. J. Geol., 97: 761-762.

Holland, H.D., Feakes, C.R. and Zbinden, E.A., 1990. The Flin Flon paleosol and the composition of the atmosphere 1.8 BY BP. Am. J. Sci., 289: 362-389.

Honnorez, J., 1981. The aging of the oceanic curst at low temperature. In: C. Emiliani (Editor), The Oceanic Lithosphere. Wiley, New York, N.Y., pp. 525-588.

Hoschek, G., 1967. Untersuchungen zum Stabilitätsbereich von Chloritoid und Staurolit. Contrib. Mineral. Petrol., 14: 123-162.

Hsu, K.J., 1988. Melange and the melange tectonics of Taiwan. Proc. Geol. Soc. China, 31 (2): 87-92.

Humphris, S.E., 1984. The mobility of rare earth elements in the crust. In: P. Henderson (Editor), Rare Earth Element Geochemistry. Elsevier, Amsterdam, pp. 317-342.

Iwao, S., 1978. Re-interpretation of the chloritoid-, staurolite- and emery-like rocks in Japan - chemical composi- 
tion, occurrence and genesis. J. Geol. Soc. Jpn., 84: 4967.

Jahn, B., Martineau, F., Peucat, J.J. and Cornichet, J., 1986. Geochronology of the Tananao Schist Complex, Taiwan, and its regional tectonic significance. Tectonophysics, 125: $103-124$.

Krois, P.K., Stingl, V. and Purtscheller, F., 1990. Metamorphosed weathering horizon from the Ötztal-Stubai crystalline complex (Eastern Alps, Austria), Geology, 18: 1095-1098.

Kronberg, B.I., Nesbitt, H.W. and Fyfe, W.S., 1987. Mobilities of alkalis, alkaline earths and halogens during weathering. Chem. Geol., 60: 41-49.

La Tour, T.M., Kerrich, R., Hodder, R.W. and Barnett, R.L., 1980. Chloritoid stability in very iron-rich altered pillow lavas. Contrib. Mineral. Petrol., 74: 165-173.

Lan, C.Y., 1989. Geochronology and rock chemistry of Taiwan gneisses. Ph.D. Dissertation, Institute of Geology. National Taiwan University, Taiwan (in Chinese).

Liou, J.G. and Chen, P.Y., 1978. Chemistry and origin of chloritoid rocks from eastern Taiwan. Lithos, 11: 175-187.

Liou, J.G. and Ernst, W.G., 1984. Summary of Phanerozoic metamorphism in Taiwan. Mem. Geol. Soc. China, 6: $133-152$.

Lu, C.Y., 1986. The origin of the lithic blocks in the Tienhsiang formation between Lo-Shao and Tsemuchiao, eastern Taiwan. Proc. Geol. Soc. China, 29: 87-97.

Ludden, J.N. and Thompson, G., 1978. Behaviour of rare earth elements during submarine weathering of tholeiitic basalt. Nature (London), 274: 147-149.

Ludden, J.N. and Thompson, G., 1979. An evaluation of the behaviour of rare earth during the weathering of sea-floor basalt. Earth Planet. Sci. Lett., 79: 1131-1141.

Marsh, J.S., 1991. REE fractionation and Ce anomalies in weathered Karoo dolerite. Chem. Geol., 90: 189-194.

Middelburg, J.J., Van der Wejden, C.H. and Woittiez, J.R.W., 1988. Chemical processes affecting the mobility of major, minor and trace elements during weathering of granitic rock. Chem. Geol., 68: 253-273.

Minarik, L., Absolon, K., Zdislava, K. and Klecka, M., 1983. Chemical changes of granite during its weathering. In: S.S. Augustithis (Editor), Leaching and Diffusion in Rocks and Their Weathering Products. Theophrastus, Athens, pp. 293-306.

Nesbitt, H.W., 1979. Mobility and fractionation of rare earth elements during weathering of a granodiorite. Nature (London), 279: 206-210.

Nesbitt, H.W. and Young, G.M., 1989. Formation and diagenesis of weathering profiles. J. Geol., 97: 129-147.

Nesbitt, H.W., Markovics, G. and Price, R.C., 1980, Chemical processes affecting alkalies and alkaline earths during continental weathering. Geochim. Cosmochim. Acta, 44: 1659-1666.

Noack, Y., Mathieu, D., Claparols, C., Loubert, M., Bernat, M. and Goncalves, N., 1990. Weathering of basalts in the north Parana Basin (Brazil): chemical aspects. In: Y. Noack and D. Nahon (Editors), Geochemistry of the
Earth's Surface and of Mineral Formation. Chem. Geol., 84: 111-113 (extended abstract, special issue).

Norrish, K. and Hutton, J.T., 1969. An accurate X-ray spectrographic method for the analysis of a wide range of geological samples. Geochim. Cosmochim. Acta, 33: 431-453.

Palmer, J.A., Phillips, G.N. and McCarthy, T.S., 1989a. Paleosols and their relevance to Precambrian atmospheric composition. J. Geol., 97: 77-92.

Palmer, J.A., Phillips, G.N. and McCarthy, T.S., 1989b. Paleosols and their relevance to Precambrian atmospheric composition: a reply. J. Geol., 97: 764-766.

Phillips, G.N., 1988. Widespread fluid infiltration during metamorphism of the Witwatersrand goldfields: generation of chloritoid and pyrophyllite. J. Metam. Geol., 6: 311-332.

Rainbird, R.H., Nesbitt, H.W. and Donaldson, J.A., 1990. Formation and diagenesis of a sub-Huronian saprolith: comparison with a modern weathering profile. J. Geol., 98: 801-822.

Retallack, G.J., 1985. Fossil soils as grounds for interpreting the advent of large plants and animals on land. Philos. Trans. R. Soc. London, Ser. B, 309: 105-142.

Retallack, G.J., 1986. The fossil record of soils. In: V.P. Wright (Editor), Paleosols, Their Recognition and Interpretation. Princeton University Press, Princeton, N.J., pp. 157.

Retallack, G.J., 1989. Paleosols and their relevance to Precambrian atmospheric composition: a discussion. J. Geol., 97: 763-764.

Robertson, A.H.F. and Fleet, A.J., 1976. The origin of rare earths in metalliferous sediments of the Troodos Massif, Cyprus. Earth Planet. Sci. Lett., 28: 385-394.

Routti, J.T., 1969. SAMPO, a Fortran IV program for computer analysis of gamma spectra from $\mathrm{Ge}(\mathrm{Li})$ detectors and for other spectra with peaks. Univ. Calif., Lawrence Radiat. Lab., Berkeley, Calif., Rep. UCRL-19542.

Schau, M. and Henderson, J.B., 1983. Archean chemical weathering at three localities in the Canadian Shield. Precambrian Res., 20: 189-224.

Schreyer, W., Werding, G. and Abraham, K., 1981. Corundum-fuchsite rocks in greenstone belts of southern Africa: petrology, geochemistry, and possible origin. J. Petrol., 22: 191-231.

Shimizu, H. and Masuda, A., 1977. Cerium in chert as an indication of marine environment of its formation. $\mathrm{Na}$ ture (London), 266: 346-348.

Sokolov, V.A. and Hieskanen, K.I., 1984. Developmental stages of Precambrian crusts of weathering. Proc. 27 th Int. Geol. Congr., 5: 73-94.

Staudigel, H. and Hart, S.A., 1983. Alteration of basaltic glass: mechanisms and significance for the oceanic crust-seawater budget. Geochim. Cosmochim. Acta, 47: 337-350.

Staudigel, H., Frey, F.A. and Hart, S.A., 1979. Incompatible trace element geochemistry and ${ }^{87} \mathrm{Sr} /{ }^{86} \mathrm{Sr}$ in basalts and corresponding glasses and palagonite. In: T. Donnelly, J. Francheteau, et al. (Editors), Initial Reports of Deep Sea 
Drilling Project, Vols. 51-53, Part 2. U.S. Gov. Print. Off., Washington, D.C., pp. 1137-1144.

Sutton, S.J. and Maynard, J.B., 1991. Multiple alteration events in the history of a sub-Huronian regolith at Lauzon Bay, Ontario. Can. J. Earth Sci., 29: 432-445.

Sverjensky, D.A., 1984. Europium redox equilibira in aqueous solution. Earth Planet. Sci. Lett., 67: 70-78.

Wahlstrom, E.E., 1948. Pre-Fountain and recent weathering on Flagstaff Mountain near Boulder, Colorado. Geol. Soc. Am. Bull., 59: 1173-1190.

Wang Lee, C., 1982. The Tananao Schist, reinterpreted. Proc. Geol. Soc. China, 25: 5-12.

White, D.W., Hem, J.D. and Waring, G.A.. 1963. The chemical composition of subsurface waters. U.S. Geol. Surv., Prof. Pap. No. 440-F, 67 pp.

Williams, G.E., 1968. Torridonian weathering and its bearing on Torridonian paleoclimate and source. Scott. J. Geol., 4: 164-184.

Wright, V.P. (Editor), 1986. Paleosols, Their Recognition and Interpretation. Princeton University Press, Princeton, N.J., $315 \mathrm{pp}$.

Yen, T.P., 1953. On the occurrence of the late Paleozoic fos- sils in the metamorphic complex of Taiwan. Bull. Geol. Surv. Taiwan, 4: 23-26.

Yen, T.P., 1959. The minerals of the Tananao Schist of Taiwan. Bull. Geol. Surv. Taiwan, 11: 1-54.

Yui, T.F., Lo, C.H. and Lu, C.Y., 1988. A speculative tectonic history of the Tananao Schist of Taiwan. Proc. Geol. Soc. China, 31:7-18.

Yui, T.F., Wu, T.W. and Jahn, B., 1990a. Geochemistry and plate-tectonic significance of the metabasites from the Tananao Schist Complex of Taiwan. J. Southe. Asian Earth Sci., 4: 357-368.

Yui, T.F., Lo, C.H. and Lu, C.Y., 1990b. Tectonic evolution of the Tananao Schist Complex of Taiwan. In: J. Aubouin and J. Bourgois (Editors), Tectonics of Circum-Pacific Continental Margins. VSP, Uttrecht, pp. 193-209.

Yui, T.F., Heaman, L. and Lan, C.Y., 1993. Constraints for the crustal evolution of Taiwan and Kinmen: preliminary $\mathrm{U}-\mathrm{Pb}$ results on granitoids. Annu. Meet, Geol. Soc. China, Abstr. Vol., pp. 38-39.

Zbinden, E.A., Holland, H.D. and Feakes, C.R., 1988. The Sturgeon Falls paleosol and the composition of the atmosphere 1.1 Ga BP. Precambrian Res., 42: 141-163. 